\title{
EMBOUZATION OF A BLEEDING ANEURYSM IN A PATIENT WITH SPONTANEOUS PERIRENAL HAEMATOMA DUE TO POLYARTERITIS NODOSA
}

Jorge Hidalgo ${ }^{1}$, Marc Crego ${ }^{1}$, María Montlleo ${ }^{1}$, Pablo de la Torre ${ }^{2}$, Jordi Bover ${ }^{3}$, Joan Caparrós ${ }^{1}$ y Humberto Villa vicencio ${ }^{1}$.

Department of Urology $y^{1}$ Department of Radiology². Department of $N$ ephrology $y^{3}$ Fundació Puigvert. Barcelona. Spain.

\begin{abstract}
Summary.- OBJEC TIVE: To report a rare case of a Spontaneous perirenal haematoma due to Polyarteritis nodosa treated with a selective embolización of the bleeding aneurysm. Polyarteritis nodosa (PAN) is one of a spectrum of diseases thet belongs to the pathologic category of necrotizing vasculitis. Spontaneous perirenal ha ema toma (SPH) is an unusual complication of PAN.

METHODS: W e are introducing a patient with SPH due to PAN .
\end{abstract}

RESULTS: The patient was treated with embolization of a left renal bleeding aneurysm of the upper interlobar artery. Pan is the most frequent vascular disease associated with spontaneous renal hematoma. Therefore the diagnosis may be difficult to determine.

CON CLUSIO N S: A selective embolization of the bleeding a neurysm is a therapeutical maneuver to be considered.

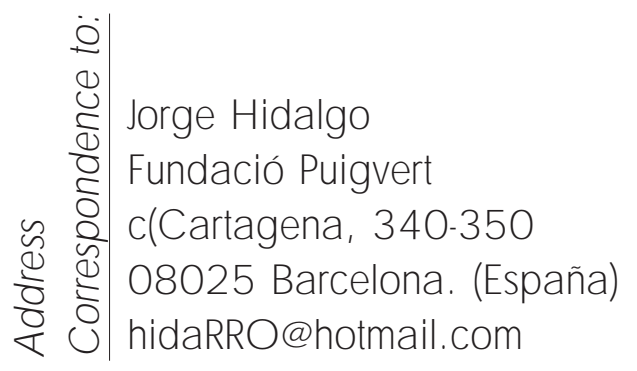

Keyw ords: Perirenal. Hematoma, spontaneous. Polyarteritis nodosa. Embolization.

Resumen.- O BJETIVOS: Presentar un caso raro de hematoma perirenal espontáneo secundario a poliarteritis nodosa tratado mediante embolización selectiva del aneurisma sangrante. La Poliarteritis nodosa (PAN les parte de un espectro de enfermedades que pertenece a la categoría patológica de las vasculitis necrotizantes. El hematoma perirenal espontáneo es una complicación infrecuente de la PAN.

MATERIAL Y MÉTODOS: Presentamos un caso de hematoma perirenal espontáneo secundario a PAN .

RESULTADO S: Se realizó embolización de un aneurisma sangrante de la arteria renal interlobar superior izquierda. La PAN es la enfermedad vascular que con mayor frecuencia se asocia con hematoma renal espontáneo. Por lo tanto, el diagnóstico puede ser difícil de establecer.

CON C LUSIO N ES: La embolización selectiva del aneurisma sangrante es una maniobra terapéutica a considerar.

Palabras clave: Perirenal. Hematoma. Espontáneo. Poliarteritis nodosa. Embolización. 


\section{INTRODUCTION}

Although in 1700 Bonet had done the first observation of the spontaneous perirenal hematoma (1), W underlich in 1856 first described the clinical picture of spontaneous renal bleeding with dissection of blood into the perinephric space characterized by lumboabdominal mass, flank pain and hypovolemic shock (Lenk`s triad) (2)

PAN is an uncommon inflamatory disorder of small and medium-size vessels (3). The kidney may be involved in $70 \%-80 \%$ of cases. Many of the clinical symptoms are related to organ ischemia secondary to arterial branch occlusions. A neurysm rupture is a less common cause of pain (4). Spontaneous perirenal hematoma as a result of PAN is an unusual clinical entity (5), and about 20 cases have been reported in the English literature from 1985 to 1999 according to Zhang's meta-analysis (6). We are submitting a case with polyarteritis nodosa who was admitted to our hospital with moderate abdominal pain, hypertension, and anemia.

\section{CASE REPORT}

A 21 year-old woman was brought to the emergency department with left-side flank pain for the last 7 days with moderate improvement. 0 ne day before admission, an abdominal ultrasonography was requested by her general practitioner (GP) and showed a solid perirenal mass arising from the upper pole of the left kidney, and a hypoechoic mass in the upper pole that in the doppler study revealed an intense vascular and turbulent pattern making us suspect upper-lobe renal artery aneurysm. A computer tomography (CT) of the abdomen showed a left perinephric hematoma. The study suggested a vascular lesion (renal aneurysm or arteriovenous fistula). There were also some identical smaller lesions in the right kidney (Figure 1). Due to these findings the patient was sent to our centre. She complained of fatigue, weight loss (8 $\mathrm{kg}$ over the last 2 months), and cutaneous lesions for the preceding 12 months. Her medical history was remarkable only for tobacco abuse. No medication intake was reported.

Thysical examination showed an alert young woman. Her temperature was $36,4 \stackrel{\circ}{ } \mathrm{C}$, blood pressure $162 / 118 \mathrm{~mm} \mathrm{Hg}$, heart rate at 100 beats/min and regular. Skin and mucosae pallor. Both the pulmonary and the neurological examination were normal. The abdomen was soft, not distended and without palpable masses.

The initial laboratory evaluation included a white blood cell count of $19.3 \times 100$, segmented neutrophils $84.4 \%$. Hematocrit was $24 \%$ and hemoglobin $78 \mathrm{~g} / \mathrm{L}$. Blood urea nitrogen $3.1 \mathrm{mmol} / \mathrm{L}$, and creatinine $75 \mu \mathrm{mol} / \mathrm{L}$. Uryanalisis was negative.

The patient was admitted for further evaluation of her anemia, hypertension and the CT findings, and it was resolved to give her conservative medical management. $\mathrm{O} n$ subsequent days the patient presented fever $\left(38.6^{\circ} \mathrm{C}\right)$ and hypertension (blood pressure $150 / 90)$. Blood and urine cultures were negative. Blood samples were obtained every day and haematocrit and hemoglobin fell down to $22 \%$ and $69 \mathrm{~g} / \mathrm{L}$ respectively. Due to these values, a blood transfusion was administered.

A CTscan was performed to evaluate the perirenal hematoma (Figure 2). A persistence of perirenal hematoma with hyperdense inner areas suggesting a

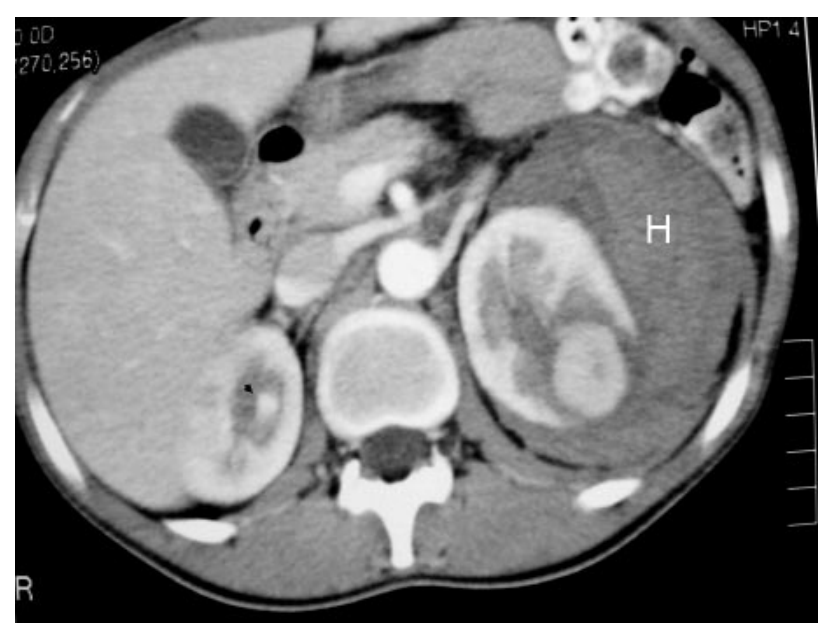

FIG URE 1. Left perineal and pararenal hematoma $(H)$ which displaces the kidney medially and the peritoneal contents anteriorly. The presence of other identically behaving nodal formations in the same section of the right kidney (arrowhead) and in other portions of the left kidney (arrows at B) suggest multiple renal a neurysms, the largest of them is responsible for the perirenal hematoma. These findings, together with the areas of multifocal segmental ischemia, are suggestive of a diagnosis of PAN. 
recent bleeding but without current signs of active bleeding were observed. A decrease of the vascular aneurysmatic lumen due to a mass effect, suggested a partial thrombosis of the vascular lesion. The smaller hyperdense vascular lesions in both kidneys were still observed. Multiple three-cornered areas without uptake of IV contrast in the parenchyma of both kidneys were seen. These findings corresponded to ischemia or renal infarction. These findings made us suspect a systemic vasculitis disease.

Due to the persistence of the anemic syndrome and the $\mathrm{CT}$ imaging findings of bleeding persistence, we decided to carry out an angiography and embolization with coils.

The segmental aortography (Figure 3) showed a normal-caliber aorta with many aneurysmatic formations in various diameters in the branches depending on the hepatic artery and both renal arteries.

The kidneys presented with cortical infarction areas, the largest one in the left upper pole centered by the largest-caliber aneurysm but with no signs of active bleeding. Selective renal angiography was performed and then embolization of the supraselective posterior medial branch that feeded the above mentioned aneurysm, by means of placing three M RI-compatible $3 \times 5 \mathrm{~mm}$ steel coils with synthetic fibres.

Faced to the evidence of multiple vascular aneurysms and with a high suspicion of PAN, we resolved

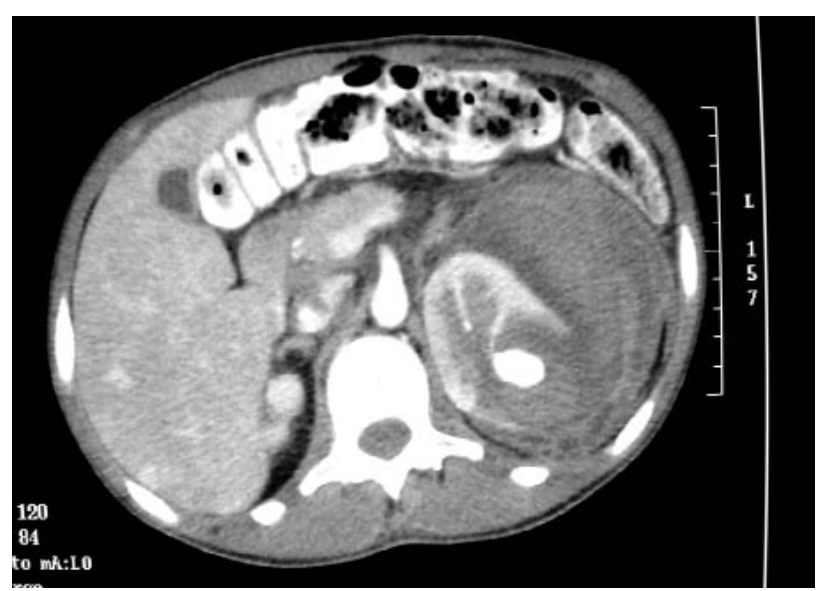

FIG URE 2. Hyperdense vascular lesions in both kidneys. Persistence of perirenal hema toma with hyperdense inner areas suggested recent bleeding, even though without signs of active bleeding. to start treatment with $800 \mathrm{mg}$ cyclophosphamide and $50 \mathrm{mg} / \mathrm{d}$ methylprednisolone as bolus, where upon we verified the disappearence of fever and asthenia, the descent of leukocytosis down to $16 \times 109 / \mathrm{L}$, and a trend to lower blood pressure figures $(110 / 70 \mathrm{~mm} \mathrm{Hg})$, which made it possible to discontinue the antihypertensive treatment. HIV and HBV were ruled out because of their high association with PAN .

A fter the embolization, CT imaging was performed in which it was possible to observe the disappearance of the aneurysm in the middle left renal portion. Persistence of the left renal hematoma and ischemic areas in both kidneys were observed. Clinical and analytical improvement was observed.

The patient was treated with cyclophosphamide, and methylprednisone. A ther latest office visit she was asymptomatic and the analytical controls proved normal.

\section{DISCUSSION}

PAN is a systemic panmural necrotizing vasculitis of unknown origin with manifestations occurring in multiple organ systems (7). Kussmaul and Maier (8) first described this difficult-to-diagnose entity in 1866. $A n$ association with hepatitis $B$ virus infection is well documented in $7 \%$ to $36 \%$ of cases of PAN (9), and also with human immunodeficiency virus (10). The kidney may be involved in $70 \%-80 \%$ of cases (4), although $\mathrm{SPH}$ is a rare complication of PAN (11). The unique

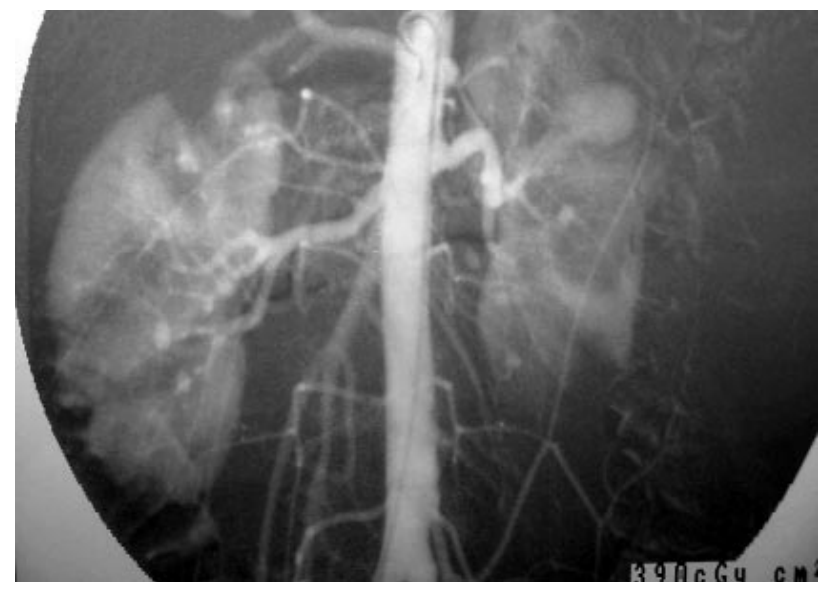

FIG URE 3. Selective segmental and renal aortography that shows multiple aneurysmal formations in middle-caliber arteries, as well as areas of segmental ischemia. 
renal hemorrhage is generally due to aneurysmal rupture but it is rarely due to bilateral aneurysmal rupture (12).

O ur patient was without a prior diagnosis of PAN and had presented with abdominal pain, anemia and hypertension, and later on she had fever. She was having constitutional symptoms, weight loss, fatigue. The patient fulfilled at least 4 of the 10 criteria for diagnosis of PAN according to the American College of Rheumatology classification (9), including weight loss, fatigue, diastolic blood pressure $>90 \mathrm{~mm} / \mathrm{Hg}$ and arteriographic abnormality. The presence of three or more criteria has been shown to have a sensitivity of $82 \%$ and a specificity of $86 \%(9)$. Perirenal and retroperitoneal hemorrhage occur in PAN either because of spontaneous arterial thrombosis or rupture of mycroaneurisms (13).

In our case, the diagnosis of perirenal hematoma was suspected by the ultrasound findings. Ultrasound is a rapid and non-invasive technique to locate the hema toma but it is insensitive in the detection of an underlying pathological condition. CT is $100 \%$ sensitive for the presence of retroperitoneal hemorrhage according to the Zhang's meta-analysis (6). In our patient it helped to identify the site of the hematoma and determined the posible diagnosis of PAN. The diagnosis of PAN is ideally made by means of biopsy of involved tissue in a patient with the appropriate clinical symptoms and laboratory data, but an angiogram provides the evidence in most cases. The best-known angiographic feature is the prescence of so-called microaneurysms in medium or small arteries, although aneurysms may be difficult to detect because they may be few in number, or confined to one organ. A complete angiographic study of the abdomen should be considered to help detect occult aneurysms (4).

0 ur patient was initially managed conservatively but the increase of the hematoma and the suspicion of PAN helped us to perform an angiogram with two purposes: diagnosis and therapy. The angiogram confirmed the diagnosis of PAN and in the same maneuver a therapeutic selective embolization was performed. In a small percentage of patients with PAN, aneurysm rupture in an organ or retroperitoneal branch may be the first clinical evidence of the disease. Embolization therapy is often the treatment of choice (14).
In addition, treatment for PAN has encompassed corticosteroids at high doses, immunosupresive drugs, and plasma exchange. These agents have improved the survival rate from $10 \%$ in untreated patients to $82 \%$ in patients treated with corticosteroids and cyclophosphamide (7).

\section{REFERENCES AND RECOMENDED READING (*of special interest, **of outstanding interest)}

1. ARA GOÑI, M.A.; LA PUENTE ARRUEBO, J.I.; SANZ VELEZ, F. et al.: "Síndrome de Wunderlich: a propósito de 3 casos". Actas Urol. Esp., 21: 158, 1997.

2. WUNDERLICH, C.R.A.: "Handbuch der Pathologie und Therapie". 2nd ed. Stuttgart: Ebner \& Seubert, 1856.

3. Chapel Hill Consensus conference 1993.

*4. STANSON, A.; FRIESE, J.; JOHNSON, M. et al.: "Polyarteritis nodosa: spectrum of angiographic findings". Radiographics, 21: 151, 2001.

5. AYLA S.; NASHUI, A.; GÜNGÖR, A. et al.: "Spontaneous bilateral rupture of kidneys in a patient with poliarteritis nodosa". Scand. J. Urol. Nephrol., 24: 319, 1990.

**6. JIANG QING ZHANG.; JULIA, R.; FIELDING KELLY, H. et al.: "Etiology of spontaneous perirenal hemorraghe: a meta-analysis". J. Urol., 167: 1593, 2002

7. PINTAR, J.T.; ZIMMERMAN, S.: "Hyperreninemic hypertension secondary to a subcapsular perinephric hematoma in a patient with polyarteritis nodosa". Am. J. Kidney Dis., 32: 503, 1998.

8. KUSSMAUL, A.; MAIER, R.: "Ueber eine bisher nicht beshriebine eigenthumliche arterienerkrankung, die mit morbus brightii und rapid fortscheitender allgemeiner muskellahmungeinhergeht". Dtsch. Arch. Klin. Med., 1: 483, 1866.

9. LIGHTFOOT, R.W.; MICHAEL, B.A.; BLOCH, D.A. et al.: "The American College of Rheumatology 1990 Criteria for the classification of Polyarteritis Nodosa". Arthritis Rheum, 33: 1088, 1990.

10. LIBMAN, B.S.; QUISMORIO, F.P. Jr.; STIMMLER, M.M.: "Polyarteritis nodosa-like vasculitis in human immunodeficiency virus infection (abstr)". Arthritis Rheum, 22: 351, 1995.

*11. SURJIT SINGH; GURWINDER SINGGH; SAVITA KUMARI et al.: "Polyarteritis nodosa presenting as perirenal hemorrhage". Urol. Int., 55: 105, 1995.

**12. ZAPZALKA, D.M.; THOMPSON, H.A.; BOROWSKY, S.S. el al.: "Polyarteritis nodosa presenting as spontaneous bilateral perinephric haemorrhage: Management with selective arterial embolization". J. Urol., 164: 1294, 2000.

13. CONN, D.L.: "Polyarteritis". Rheum. Dis. Clin. North Am., 16: 341, 1990.

**14. HACHULA, E.; BOURDON, F.; TAIEB, S. et al.: "Embolization of two bleeding aneurysms with platinum coils in a patient with polyarteritis nodosa". J. Rheumatol., 20: 158, 1993. 